\title{
THE MILITARY SURGEON: HIS PLACE IN HISTORY
}

\author{
P B ADAMSON
}

SUMMARY: The military surgeon is an officer who is usually held in high esteem by his colleagues in the modern army. This has not always been the case in the past however, and this present study is an attempt to trace his origins from antiquity to the position which he holds in the modern British army.

\section{Introduction}

Although treatment of wounds and fractures must have been given to casualties from the earliest periods of human history, the results of serious injuries in antiquity were usually fatal; occasionally, however, there is evidence that medical intervention may have prolonged life $^{1}$. It may be assumed that primitive man had some basic concepts of therapy, but treatment was probably more closely allied to the practice of witchcraft and magic than to genuine medicine.

The discovery of writing originated in Mesopotamia early in the third millenium BC, and the art of writing was soon copied by the Egyptians. It is reasonable to suppose that major advances in medical knowledge were only likely to take place after the recording of facts was made available for posterity to study. The practice of medicine therefore most probably originated in the countries of the ancient Near East, Egypt and Mesopotamia being the principal protagonists of medicine and writing in that area ${ }^{2}$.

The oldest medical texts known at present date from the end of the third millenium BC, but may be copies of even earlier texts which have not been preserved $^{3}$. Egyptian and Mesopotamian medical practice strongly influenced neighbouring countries for the next two thousand years, being finally superseded by the Hippocratic system of medicine from Greece. Although there was a moderate degree of interchange of medical knowledge between Egypt and Mesopotamia, in general the two systems of medical practice remained independent of one another.

\section{Historical background and discussion}

In Egypt and Mesopotamia doctors were derived from the educated class, being closely associated with scribes and priests, and consequently able to read their own medical texts. However, throughout most of pharaonic history, the physician of Egypt remained under control of the priesthood. Medical treatment therefore remained very conservative, relying on the well-tried official remedies of ancient authorities; ${ }^{4}$ in Mesopotamia, on the other hand, the physician came under control of the king and not the priesthood, and had therefore greater latitude in medical treatment ${ }^{5}$. Physicians from both countries were frequently sent to foreign courts to render medical assistance to friendly rulers and their officials ${ }^{6}$.

The physician was a member of the royal court, being responsible for the health of all members of the court, including military personnel and their dependants. He was expected to accompany the ruler when he went to war, and remained 
close to the military commander in the field ${ }^{7}$, being considered too valuable to be exposed to danger in the van of the army. Although medical services may have been adequate for the military high command, they were certainly inadequate for the majority of the fighting troops, for the sanitary corps was totally unknown at this time to military commanders in the field ${ }^{8}$.

The ancient Hebrews appointed priests and levites to serve the Lord of Hosts in wartime; they accompanied the army to war and actively served in the field ${ }^{9}$. Public health measures and personal hygiene were strictly enforced for religious reasons. There was no appointment of military surgeons; priests merely extended their normal duties in the theocratic state by rendering medical assistance to all members of the military congregation, irrespective of their social position in the army. Hittite medicine during the second millenium $\mathrm{BC}$ was dependent on teachings and practitioners from Mesopotamia. It is remarkable that even as late as the Siege of Troy (c 1200 BC), there were no official doctors appointed to the fighting troops; the few physicians who were present in the field were scarce in numbers but highly valued for their technical skills ${ }^{10}$.

This unsatisfactory state of affairs was prevalent throughout all countries in the Near East during the second millenium BC, but from the commencement of the first millenium, the status of physicians in wartime tended to change for the better. The gradual rise to power of Assyria created political conditions inside this state which were ideal for the emergence of the military surgeon. The King was supreme commander of the Assyrian army, responsible only to the national god Assur, and the state was administered on the lines of a true military hierarchy. From the reign of King Tiglath-Pileser III (745 to $727 \mathrm{BC})$ a permanent standing army was maintained, and numerous garrisons were established throughout the Empire in order to enforce the Assyrian peace ${ }^{11}$. Court physicians had now become highly esteemed officials, many of whom are known to us by name and who had direct access to the King; no longer were they civilians but were classed as surgeons in the Assyrian army. They were responsible for the health of the king or his representative, maintained the fitness of the fighting troops, and supervised the general health of skilled technicians and groups of prisoners.

Movements of large numbers of peoples within the boundaries of the Empire required strict administration of public health measures by the medical authorities even in peacetime ${ }^{12}$, but when applied to the Assyrian army in the field, these measures were not always successful ${ }^{13}$. By the 7 th century $\mathrm{BC}$ the military surgeon had fully justified his position in the Assyrian army and had achieved maximum influence during the reigns of Kings Esarhaddon and Assurbanipal. Records show also that physicians were considered as valuable prisoners of war by the Assyrians ${ }^{14}$.

The military surgeon of Assyria was a direct descendant of the civilian physician employed at the royal court of Mesopotamia. He was a product of the military state, and for the first time in recorded history a military state provided its army with adequate medical facilities at all times. The Assyrian surgeon was fully appreciated at his true worth, and provided invaluable service to the whole community, yet, with the total collapse of the Assyrian Empire and 
the destruction of Nineveh in $612 \mathrm{BC}$, his disappearance from the military scene was absolute. This is perhaps not too surprising when it is remembered how deeply Assyria, and all it stood for, was loathed and feared by her neighbours; without any doubt the military surgeon disappeared in the complete destruction of the hated Assyrian army. At the same time, the magnificent library of King Assurbanipal, which contained numerous medical texts useful to surgeons, had been burnt and destroyed; medical teaching must have suffered badly in consequence. Thus, the first successful emergence of the military surgeon had no lasting impact on the development of military medicine in future world history.

The power vacuum left by the eclipse of Assyria was soon filled by the Babylonians and Persians in the ensuing centuries, but neither power followed the Assyrian method of military government. The kings of Persia reverted to the earlier system of having civilian physicians at court, Greek physicians who took part in military operations ${ }^{15}$. Persian military expeditions against Greece, although ultimately unsuccessful, provided further oppontunities for Greek medical influences to be diffused widely throughout Asia Minor.

Conditions in ancient Egypt remained relatively unchanged throughout the centuries, and even the temporary conquest of the country by the Assyrians hardly changed the conservative outlook of the Egyptian doctors. But during the XXVIth dynasty. Pharoah Amasis (570 to 526 BC) instigated close ties with Greek mercants, and Greek medical influences gradually became strong throughout Egypt, as evidenced by the assimilation of the deified Imhotep to the Greek god Asklepios ${ }^{16}$. The important, but ancient, medical school at Sais was renovated during the latter part of the 6th century $\mathrm{BC}$ by order of Darius I of Persia; who certainly employed Greek physicians at his own court ${ }^{17}$. Egypt continued to be strongly influenced by Greek medical thought throughout the period of the XXVI to XXXth dynasties (c 570 to $335 \mathrm{BC})^{18}$. Following the conquest of Egypt by Alexander the Great in $332 \mathrm{BC}$ and the establishment of Alexandria as the most important centre for medical training, the practice of Hippocratic medicine was soon disseminated throughout the whole of the ancient Near East. Alexander himself recognised the necessity of providing adequate medical services for his troops, and may have indeed been the first commander who attempted to organise medical services for officers and troops when on active service ${ }^{19}$. Unfortunately, after his death in $332 \mathrm{BC}$, doctors in the Hellenistic world were relegated once more to the level of relatively poorly paid technicians, and were no longer considered to be skilled military surgeons ${ }^{20}$.

The emergence of the Roman Empire in the West led to the formation of the legions. At first these troops had minimal medical attention, crude medicine and surgery being practiced by the soldiers upon themselves ${ }^{21}$, but with the conquests of Egypt and Greece, the Romans were influenced by Greek civilisation, and the Roman general soon was accompanied by his personal physician on the battlefield ${ }^{22}$; the earliest physicians were Greek and were not held in much repute by the Romans ${ }^{23}$. By the end of the Second Punic War (201 BC), the Roman army was still deficient in medical services ${ }^{24}$, but this omission was soon rectified, for by the 1 st century BC the "medicus" was an official medical aide attached 
to the Roman legion, providing medical services to the legionary ${ }^{25}$. The provision of sick quarters and the "valetudinarium" was a further attempt to maintain the fighting strength of the legion at maximum efficiency, for these hospital services were an integral part of the military "castrum". Nevertheless, neither properly organised medical services nor military surgeons were provided for the Roman armies by the Government of $\mathrm{Rome}^{26}$, physicians being appointed individually to each legion. By the beginning of the present era, better conditions of service had attracted doctors who were often slaves or freemen into the army, usually being rewarded with the status of Roman citizen for their services. These doctors were skilled in their profession, and were already making important contributions to medical knowledge ${ }^{27}$. The Emperors themselves also took an active interest in the welfare of their troops ${ }^{28}$.

Once again, the military surgeon had appeared on the scene. The Roman surgeon had originated from Greek civilians practising Hippocratic methods, who were initially attached to individual commanders in the field. The establishment of permanent garrisons naturally required an expansion of the medical services, and led to increased numbers of trained military surgeons, many of whom were Romans themselves ${ }^{29}$. During the conquest of the British in the early centuries of the present era, the Roman legions were assisted by auxiliaries recruited in Britain itself. Military surgeons bearing Latin names were attached to the invading troops, but may have been enrolled from local tribes in Britain $^{30}$. Fortunately for the troops in Britain, they enjoyed some measure of financial independence from the central government at Rome. Nevertheless, the military surgeon in Britain remained at a relatively low social level, thus probably reflecting the lack of funds which were necessary to attract suitable trained recruits to the army. No doubt his civilian counterpart must have been tempted by higher salaries and better living conditions to practice his art in larger cities ${ }^{31}$. The Roman military surgeon certainly did not enjoy the social status nor financial rewards granted to his Assyrian predecessor, nor were his services fully appreciated by the government at Rome. His position appears to be that of a modest citizen employed as a skilled technician in the army. Roman military control over most of Britain lasted from the 1st to the 4th centuries of the present era, but on the withdrawal of Roman garrison troops, the tribes in Britain reverted to barbarism, and all traces of the Roman military surgeon vanished. This must surely reflect poor conditions of service and the inability to maintain a permanent force for peace by the local inhabitants ${ }^{32}$.

Although traces of Roman military influence still lingered on under AngloSaxon and Norman rule ${ }^{33}$, feudalism and the military levy (fyrd), instituted from the reign of Alfred the Great in the 9th century, were also employed by the Norman Kings of England ${ }^{34}$, and military medicine remained at a low ebb. Doctors, often quite unskilled in their art, were called upon for temporary military service by lords of the manor, but the provision of hospitals for troops was virtually non-existant. The Church, by providing medicines and beds for the sick, attempted to alleviate the sufferings of the poor, but was incapable of coping with large numbers of military casualties ${ }^{35}$. The standard of military 
medicine remained at an abysmally low level during the ensuing centuries of the Middle Ages. Physicians who accompanied the Crusaders were usually so incompetent or inexperienced in tropical diseases that they were forced to undergo examinations before being allowed to practice in Jerusalem ${ }^{36}$. The Black Death and the Hundred Years' War between France and England during the 14th century led to even further medical stagnation; alchemy and magic now flourished at the expense of genuine medical knowledge ${ }^{37}$.

With the advent of gunpowder in warfare during the 16th century, the necessity for having competent surgeons to treat casualties became acute, but only in $1645 \mathrm{AD}$ did the New Model Army under Cromwell at last provide acceptable conditions of service for medical practitioners. Medical officers were now appointed to this standing army on a permanent basis and given adequate renumeration for their services. The professional military surgeon had appeared for the third time in history. There were now opportunities for advancement within the ranks for suitably qualified candidates and professional merit was rewarded $^{38}$. Cromwell therefore may be considered to be the first British commander who recognised the value of properly trained military surgeons in the field. Permanent armed forces were maintained in England until their disbandment by Charles II, but even then a small band of regulars was kept for guard duties ${ }^{39}$; political and military necessity however soon required an expansion of the military establishment. At this time, the military surgeon was still a relatively insignificant member of the officer class. Although practising modern medicine based on Hippocratic precepts, he had developed from neither of his predecessors. He originated from the establishment of the Standing Army of Charles II, which itself followed directly on from the army of Cromwell. He himself was usually individually appointed as regimental surgeon, nevertheless well qualified civilian surgeons were still being called upon for the duration of hostilities who were mainly allocated to large hospitals or to staff appointments. The position of the military surgeon, compared to that of the military physician who often obtained better conditions of service and was appointed by civilians, remained unsatisfactory, until the Peninsular War of the early 19th century provided an opportunity to improve medical services for the troops, and better conditions for surgeons in the field ${ }^{40}$; this was mainly due to the efforts of Sir James McGrigor who served with success under the Duke of Wellington ${ }^{41}$. The difference between military physicians and surgeons now began to disappear, both types of officer coming under the control of the Army Medical Department ${ }^{42}$, but, even as late as the time of the Crimean War, doctors were scarce, mainly due to unacceptable conditions of pay ${ }^{43}$. It was significant that Florence Nightingale, together with other civilians, was ably assisted by military surgeons in the Crimea to reorganise and improve nursing and welfare services for the British troops, thereby causing a dramatic drop in mortality of the wounded, whose treatment previously had often been primitive in the extreme ${ }^{44}$. The conclusions of the official Select Committee in 1856 led to improvements in medical administration, better conditions of service for doctors, and provision of adequate medical supplies to the army ${ }^{45}$, benefits which have indeed been maintained and even improved upon to the present day. 
It can be clearly seen that throughout history, the military surgeon has been a product of a political system in which a permanent army was maintained by the establishment; without a permanent standing army he ceased to exist. When the central government was strong and willing to assist in matters medical, the military surgeon flourished and provided excellent service to the community, both civil and military. However, unless adequate remuneration and reasonable terms of service were provided, the best type of officer was not attracted to the services and the health of the troops suffered in consequence. History strongly suggests that only a centralised medical service is capable of providing adequate cover for the troops, and the professional status of the military surgeon is reflected according to the efficiency of this administration.

It is of considerable interest to note that medical officers in the "modern" British army were expected to supervise the infliction of punishment by flogging, and had personally to brand deserters on the chest ${ }^{46}$. In antiquity all forms of branding and mutilation by medical practitioners were strictly prohibited in the countries of the ancient Near East, severe penalties being imposed for any infringement of the law ${ }^{47}$. Both forms of punishment were however inflicted by officials, but in the case of flogging the number of strokes awarded was noticeably fewer than those in British punishments ${ }^{48}$. Curiously enough, the Persian army was actually lashed into battle, no doubt "pour encourager les autres", but victory was not an invariable consequence of this action ${ }^{49}$. Severe military punishments were inflicted on, and by, Roman soldiers, but were not necessarily carried out in the presence of a military surgeon ${ }^{50}$. Public opinion in Britain being against barbarities, such forms of punishment were abolished by the end of the 19 th century ${ }^{51}$, and the military surgeon no longer had to supervise them as part of his official duties.

\section{BIBLIOGRAPHY}

1 ANDerson, J E. Human skeletons of Techuacán. Science 19்5; 148: 496-497. See p497: four early skeletons of E1 Riego phase ( 6800 to $5000 \mathrm{BC}$ ) with healed fractures. FERIZ H. War and surgery in ancient Peru. Abbotempo 1968; 1: 28-31. Pales L. Neolithic trepanned skulls. Paléopathologie et pathologie comparative. Paris. Masson 1930; P 76 . Neanderthal man (middle Palaeolithic): healed fracture of left humerus; p 89-97: Flint wounds: Neolithic, Peruvian skull and bones of foot (Musée de Paris (Anthropologie) No 5193, 17185, 17189-17191). MaLlin $R$ and RathburN T A. a trephined skull from Iran. Bull NY Acad Med 1976; 52: 782-787. See p 782 Iron Age II skull (c 100-800 BC). SMITH $G E$ and JoNEs $F$ W. The archaeological survey of Nubia (report for 1907 to 1980). Vol II. The human remains. Cairo. National Printing Department 1910. p 337-340: Pl XLI, Fig 3, PI XLIII, Fig 2.

2 ChoH-LuH LI. a brief outline of Chinese medical history with particular reference to acupuncture. Perspect Biol Med 1974; 8: 132-142. See p 132. Chan KaI ChING. The history and romance of acupuncture. Med $J$ Malaysia 1963; 18: 16-18. Chinese medicine had a long oral tradition but written records only appear $c 1500 \mathrm{BC}$. In antiquity, there was no contact between China and the Middle East in matters medical.

3 Crvil M. Prescriptions' médicals sumériennes. Rev. Assyriol 1960; 54: 57-72. Texts CBS 14221, HS 1883 from Nippur. BREASTED J H. Edwin Smith Surgical Papyrus. Vols 2. OIC 3. Chicago. University of Chicago Press 1930. Ebbell B. The Papyrus Ebers. London. Milford 1937.

4 A-P LeCa. La Médecine Egyptienne. Paris. DaCosta. 1971. p 122. Diodorus Siculus. Library of History. 1.82.3. 
5 Oppenheim A L. Ancient Mesopotamia. Chicago and London. University of Chicago Press 1964. p 302. A FINET. Private practice was permitted. l'annuaire de l'Institut de Philologie et d'Histoire Orientales et Slaves. Tome XIV (1954-57). Bruxelles. 1967. p 123-144. See p 133: Text A 140. Dossin G. Archives royales de Mari. Paris. Imprimerie nationale 1946. I. 28. 115; 1951; IV; 63: 5-13.

6 Knudtzon J A. Die El-Amarna Tafeln. Vol. 2. Leipzig. Hinrich 1915. See TA 49: 22-25. MEISSNER B. Babylonian und Assyrien. Vol 2. Heidelberg. Winter 1925. p 285, quoting text KUB III. 67: rev 1 ff. FuguLLA H H and WEIDNER E F. Keilschrifturkunden aus Boghazkoi. (=KUB) WVDOG 30/1. Leipzig 1916. See 1. 10: rev 34 ff. Fines ibid. text A 2756. LeCA op cit, note 4. p 115.

7 LeCA, ibid, p 113. DioDorus, op cit, note 4.

8 Note the complaints in papyrus Lansing of the XXth dynasty ( $c$ 12th century BC) (Blackman A $M$ and PEAT T E. Papyrus Lansing: a translation with notes. $J$ Egypt Archeol 1925; 11: 284-298. See text 9. 5-10. 5) and papyrus Deir El-Medineh 35 recto (SAUNERON S. disillusions of the Asiatic war: Pap. Deir El-Medineh 35. Kémi 1968 18: 17-27, seven lines in text in literary script of the New Empire).

9 Num; 1: 51-53; 27. 21. Tract Yoma 73a. GASTER T H. The Scriptures of the Dead Sea sect. London Secker and Warburg 1957. p 262-263: II 1-6; p 269-270; VII 8 ff.

10 HOMER Iliad; 11: 514.

11 SAGGS H W F Assyrian warfare in the Sargonid period. Iraq 1963. 25: 145-154, see p 145.

12 SAGGS H W F. The Nimrud letters 1952 - part IX. Iraq; 1974 36: 199-221, see letters XCVI 17-39; XCVIII. obv 1-10; cv obv 4' -rev 20'. Note also Ki. 17. 24; 18.11.

13 2 Ki. 19. 35; 2 Chron. 32. 21. Compare Herodotus. Hist; 2: 141.

14 Oppenheim A L. Babylonian and Assyrian historical texts. In Ancient Near Eastern Texts. ed J B PRITchard. New Jersey. Princeton University Press 1969. 3rd ed. p 265-317, see p 293; Dog River Stela 7-end.

15 Xenophon. Anabasis 1: 8. 26-27; Cypropaedia. 3. 2. 12. Ctesias of Cnidus fought under Artaxerxes II in the Persian War of 401 BC (FILlozat J. The Classical Doctrine of Indian Medicine. Delhi. Lal. 1964: $\mathrm{p}$ 246). Apollinides of Cos was at the court of Artaxerxes I from c 464-440 BC (Plutarch. Parallel Lives: Artaxerxes XIII. 3-4).

16 KeEle K D. Imhotep, from man to god. Clio Med 1966; 1: 147-151, see p 149-150. LECA, op cit, note 4, p 93-95.

17 LECA. ibid, p 123. translation.

18 Gardiner A H Egypt of the Pharoahs. Oxford. Clarendon Press 1962. p 368-378.

19 AdAMSON P B. The influence of Alexander the Great on the practice of medicine. Episteme 1973; 7: (3). 222-230, see p 225.

20 RostovtzefF $M$. The social and economic history of the Hellenistic World. Vol 3. Oxford. Clarendon Press 1941. p 146-1601.

21-23 Tacitus. Hist; II: 45. 22. Plutarch. Parallel Lives: Marius 6. 3; Caesar 34. 3; Pompey 2. 5-6. 23. Pliny. Nat Hist. XXIX; viii: 16-17.

24 Yuval A. The military medical service during the second Punic War according to Livius XXI-XXX, Koroth 1970; 5: (5/6): LVI-LVII.

25 SCARborough J. Roman medicine and the legions: a reconsideration. Med Hist 1968; 12 (3): 254-261, see p 254 n1, p 256 n12. Cicero. Tusc Disp II. 16.28.

26 Nutton V. Medicine and the Roman army: a further reconsideration. Med Hist 1969; 13 (3): $260-270$, see p 260-264.

27 For example, the pharmacopoeia of Dioscorides (The Greek Herbal. ed R T GUNTHER. New York. Hafner 1959); surgical treatments, including wounds of gladiators, by Galen Opera Omnia. (ed C G KUHN). Leipzig. Cnobloch 1821-1833; siting of the valetudinarium by Hyginus Gromaticus and principles of military hygiene by Vegetius (PENN R G. Medical services in the Roman Army. $J R$ Army Med Corps 1964; 110: 253-258). The practical application of Vegetius' teachings noted in the field (DAviES $R$ W. Saalburg Jahrb 1970; 27: 84-104, Brit Archaeol Abstr 1971; 4: abstr 1041).

28 Scriptores Historiae Augustae. Vol 3. ed D Magie. London. Heinemann 1960. 1. Hadrian X.6; 2. Severus Alexander XLVII. 2-3.

29 Allbutt T C. Greek medicine in Rome. London. MacMillan 1921. p 423.

30 Webster G. The Roman Imperial Army. London. Black 1969. p 250: Scribonius Largus, $M$ Ulpius Sporcus, $M$ Rubrius Zosimus. SonNTAG C F, The History of baths and bathing in Britain before the Norman Conquest. Proc $R$ Soc Med (Hist Med Sect) 1920; 13: 25-45, see p 36 fig 7. Maurelius Habrocomus; $p 39$ fig 13; Anicius Ingenuus; fig 14: Hermogenes. NutToN V. A Greek doctor at Chester. J Chester Archaeol Soc 1968; 55: 7-13, see p 7-9: Antiochus. 
31 Pliny. Nat Hist XXIX. v. 7-9. Budge E A W. The Syriac Book of Medicines. 1913. Vol 2. London and New York. Milford. Introduction CLXXV: DrrTrICK H. Fees in medical history. Ann Med Hist 1928; 10: 90-101.

32 Cantuie N. A history of the Army Medical Department. Vol 2. Edinburgh and London. Churchill Livingstone 1974: 1: 1 .

33 Freeman E A. The history of the Norman Conquest of England. Vol 5. Oxford. Clarendon Press 1870. 2nd ed; 1: 91-92; 5: 372.

34 Thomas C. The coveted isles, in The Dark Ages. ed D T Rice. London. Thames and Hudson 1969. p 242-268, see 268.

35 CANTLIE N. op cit, note 31, see; 1: 10-13.

36 Runciman S. A history of the Crusades. Vol 3. Harmondsworth. Penguin Books 1971; 2: $318 \mathrm{nl}$, 320. AMUNDSEN D W. The medical legislation of the assizes of Jerusalem. Proc XXIII Interim Congr Hist Med 1972. London. Wellcome Institute of the History of Medicine 1974; 1: 517-522, see p 519.

37 See description of the 'Docteur of Physyk' given by G Chaucer (The Canterbury Tales: The Prologue).

38 Barnett C. Britain and her Army. London. Penguin Press 1970; p 98. Cantlie N. op cit, note 32, see; 1: 123. SchadewaldT H. Bedeutende Militãrärzte und ihr Einfluss aus die Entwicklung der Medizin. Wehrmed Mschr 1968; 12: 152-160. Note that advances in surgical technique were often influenced by surgery during wartime.

39 FeILING K. A History of England. Oxford. Book Club Associates 1974: p 540.

40-43 Cantlie N. op cit, note 32, see 1: 294. 296. 41: Cantlie N. ibid. 1: 296. 452. 42. Cantlie N. ibid. 1: 3. 294. 43. Cantlie N. ibid, 2: 132.

44 BARNETT. op cit, note 38, see $\mathrm{p} 2285$. 289. A personal account of conditions in the Crimea given by T. Gowing (a Voice from the ranks), ed K Fenwick. London. Folio Society 1954, p 57-58.60.63-68.

45 The Sanitary Commission and the McNeill-Tulloch Commission of 1855 led to the conclusions of the Select Committee on the Medical Department following the Crimean War in 1856 (C WoodHAM-SMITH. Florence Nightingale. London. Reprint Society 1952. p 162-164. CANTLIE N. op cit, note 32, see 2: 199-201).

46 CANTLIE N. ibid 1: 446, and quoting Queen's Regs. 1 July 1844, para 30.

47 Driver G R and Miles J C. The Babylonian Laws. Vol 2. Oxford. Clarendon Press 1955. See 2: 82. CH paras 146. 227. Note also Middle Assyrian Laws, paras 57. 58 and possibly F1 (MEEK T J. The Middle Assyrian Laws. In Ancient Near East Texts. ed J B Pritchard. Princeton. Princeton University Press 1969. 3rd ed: $p$ 180-188, see p 185. 187), and Hittite Laws, paras 11-16. 60-62. 77B and 163 (GOETZE A. The Hittite Laws. In Ancient Near Eastern Texts. ibid, p 188-197, see p 189. 192. 195).

48 MeEk T J. ibid. p 182, para 40. p 186. paras 7-10. 13. 15. 18. p 187, paras 2. 3. 8. E1. F1. p 188, paras N1-2. Compare Jewish Law in Deut 25. 2-3 and Mishnah: Makkoth 3. 10. 11. 14 .

49 Herodotus. Hist 7. 223. Xenophon. Anabasis. 3. 4. 26.

50 Select Papyri. (ed A J Hunt and C C EdGar). Vol 3. London. Heinemann 1963. See 2: No 254 dated 153 AD. Soldiers captured by the Romans were often branded and sold as slaves. Appian. Roman History: Hannibalic War. VII: 43. Wars in Spain. VI: 38).

51 BLANCO R L. Attempts to abolish branding and flogging in the Army of Victorian England before 1881. J Soc Army Hist Res 1968; 46: 137-145. 